\title{
Studies of the Floral Biology and Reproductive System of Brassica napus L.(Cruciferae)
}

\author{
Rosilda Mara Mussury ${ }^{1 *}$ and Wedson Desidério Fernandes ${ }^{2}$ \\ ${ }^{1}$ UNIGRAN (Centro Universitário da Grande Dourados) - Rua Balbina de Matos 2121 - Dourados, MS. ${ }^{2}$ UFMS \\ (Campus de Dourados/Departamento de Ciências Exatas e Biológicas - Dourados, MS - Brasil.
}

\begin{abstract}
Studies of the floral biology of canola were accomplished with the objective of enlarging the system and reproductive strategies knowledge of its CTC-4 cultivar in Dourados, Centerwest, Brazil. Brassica napus is self pollinated, presenting however, many resources for the allogamy accomplishment, e.g., abundant pollen, nectar and scent production. The smaller anther were responsible for the production of fruit with smaller and less growth seeds, when compared to the autogamy, autopollination and cross pollination tests.
\end{abstract}

Key words: Brassica napus, Canola, floral biology

\section{INTRODUCTION}

Among the plants with an economical importance, it is the family of the cruciferae, including about 350 kind and more than 4.000 species, with a great number of cultivated varieties as cabbage, cauliflower, brócoli, the kale and mustard among other potherbs (Barroso, 1978).

Canola (Brassica napus L.) is an improved variety of colza (Brassica oleracea L., and Brassica campestris L.), developed by Canadian researchers in the sixties (Dias,1992). In Brazil, canola is cultivated mainly in the states of Paraná and Rio Grande do Sul, with the concern of minimizing problems with the use and conservation of the soil, occurrence of plagues, diseases and harmful plants, supplying from its seeds an oil of excellent quality (Dias, 1992). According to Martin \& Júnior (1993), the species of this kind have been used as green fertilizer in the rotation of cultures, and it is indicated to protect the soil that was cultivated in the summer and it is exposed during the months of winter, besides possessing a great melliferous potential. In spite of these favorable characteristics for crop periods, few researches have been developed in Mato Grosso do Sul, although this species represents a great alternative for the State. In the studies of floral biology, the essence production from the flowers has a great importance, influencing the behavior of bees that recognize them from any distance (Proctor \& Yeo,1975; Faegri \& Van Gives Pijl,1979).

A study developed by Williams (1980), confirmed that colza flowers produced nectar and pollen in abundance and they were extremely attractive to the bees. It was observed that when bees were present, the plants produced more seeds for síliquas, besides the same ones were larger and viable. Although Williams (1985), observed in a colza plantation, that the bees collected pollen and nectar, and that the pollen concentrations transported by the wind were larger in the hot, dry and sunny days than in cold, humid and cloudy days. Williams (1978), checked that wind, transporting considerable amounts of pollen in the field, promoted the autopollination and the crossed pollination of the flowers, still influencing in the fruit yield with longer beans, which contended more seeds and a larger weight. According to Free \& Nuttall (1968), preferential schedule

\footnotetext{
* Author for correspondence
} 
visit in the colza flowers were between 9 and 10 hours. Eisikowtich (1981), showed that the wind can help the auto-pollination.

With the objective of understanding the mechanism of canola reproduction, in order to obtain subsidies for its handling and appliance, its floral biology and reproductive system were studied.

\section{MATERIALS AND METHODS}

In 1997, the studies of floral biology were accomplished in the period from July to October in stonemasons measuring $1.5 \times 10 \mathrm{~m}$, placed in an experimental area at UNIGRAN (Centro Universitário da Grande Dourados), in Dourados, MS (22 $14^{\prime} \mathrm{S}$ and $\left.54^{\circ} 49^{\prime} \mathrm{W}\right)$.

Seeds of Brassica napus were used (cultivar CTC-4), sowed with spacing of $20 \mathrm{~cm}$ among the arrays and with 12 plants for linear meter. To observe the morphology of the flower and the sequence of events that precede the anthesis, 20 floral buttons were used in different development stages. The following characteristics were observed: the dehiscence of the anthers, essence production, lipid substances and starch in the pollen grains, receptivity of the stigma, activity of the nectaries in function of the presence of the polinators and presence of sugar in the exudation. For analysis of morphology and viability of pollen grains of the anthers, acetic carmim was used according to the methodology proposal by Linsley \& Cazier (1963) and Lawrence (1966).

The anthers were observed under magnifying glass to verify the dehiscence type and the beginning of this process was correlated with the stage of the floral development. With the purpose of detecting the essence presence, thirty flowers were placed tightly in closed recipients for a period of 60 minutes and then opened and smelled, according to the technique suggested by Almeida (1984) and Dafni (1992). For the verification of lipid substances in the exina of the pollen grains and the presence of starch, the reagent Sudan III and Lugol were used, respectively (Johansen, 1940).
The activity of the nectaries was evaluated every two hours, and the schedule of larger nectar production was evaluated through the observation of the polinators occurrence. These were weekly collected with entomológic net at 7:00, 9:00, 11:00, 13:00, 15:00 and 17:00 hours. The type of sugar in the nectar was identified in the aqueous extract of macerated nectaries, it was analysed uzing Molisch, Benedict and Bial reagents, to detect the carbohydrates, reducing sugar and fructose, respectively, (Morita \& Assumpção, 1972).

To study the reproductive system, autogamy, xenogamy, crossed pollination, smaller anthers and natural pollination tests were performed. For each test, the following characters were appraised: mean size of the fruit, mean number of seeds per fruit, mean weight of the seeds, germination percentage, and mean height of the plant seeds.

\section{Autogamy}

The autogamy was evaluated through the sacking of 20 inflorescences and of 20 individualized floral buttons of $0.6 \mathrm{~cm}$. The inflorescences and the buttons were sacked $24 \mathrm{~h}$ before the floral anthesis, with thin fabric sacks, endowed with breathing pores and observed daily until the obtaining of fruit that were measured in length.

\section{Xenogamy}

The xenogamy tests were totally accomplished in 25 buttons emasculated before the dehiscence of the anthers. Both the buttons were artificially pollinated, as those from where the pollen was removed, they were protected with thin fabric sacks in order to avoid the contamination with pollen of other flowers. Immediately after the anthesis, the flowers were pollinated. The pollen was taken from the stigma by means of a dissection needle previously sterilized. Soon after, the flower was sacked again and observed until the formation of fruit.

\section{Crossed pollination}

The crossed pollination was evaluated in 20 floral buttons, emasculated before the dehiscence of the anthers. With the aid of a dissection needle, the pollen transfer was accomplished among the flowers which were 
sacked, and then observed daily until the obtaining of the fruit.

\section{Natural pollination}

For this test, 30 floral buttons were marked with colored ribbon to verify the mean number of fruit produced under natural conditions.

\section{Smaller anthers}

To observe the fertility of the pollen grains of the smaller anthers, the larger anthers of 20 floral buttons were removed with $0.6 \mathrm{~cm}$ of length. Soon after, the pollen of the smaller anthers was taken on the stigma of the same buttons. The development of the fruit was daily accompanied.

\section{Appraised characters:}

\section{Fruit size and number of seeds}

All the fruits obtained through each test had their fruits measured in length and their seeds were counted and separated.

\section{Mean weight of the seeds}

The mean weight of the seeds was obtained accurately through the evaluation of five lots of ten seeds in analytic scale of $0.1 \mathrm{~g}$.

\section{Germination test}

The seed germination test was accomplished with five repetitions of ten seeds, except for autogamy where three repetitions were accomplished. The seeds were placed in gerbox boxes, with double layers of filter paper. The boxes were placed in cold at $10^{\circ} \mathrm{C}$ for dormant break. After seven days, the boxes were placed in a germinator and maintained during a period of five days, the number of normal plant seeds was computed at the end.

\section{Plant seeds size}

The plant seeds were measured in total length (from hypocotyl to radicle), which obtained the length average of 10 plants (three repetitions for each test). To study the reproductive system, six treatments, [autogamy test, crossed pollination, xenogamy, natural pollination and smaller anthers]. Were studied and the obtained results were transformed in $\sqrt{x}+0,5$. The germination percentages were transformed for arcsine $\sqrt{ } \mathrm{x} / 100$.

The number of repetitions varied in function of the appraised characters, and the average of the treatments for the appraised characters were compared by the test of Tukey at the level of 5\% of probability.

\section{RESULTS AND DISCUSSION}

The flowers of $B$. napus present four sepals, four petals, four longer stamens and two shorter stamens. The anthers present longitudinal dehiscence. The ovary is a superior type, with parietal placentation, gamocarpelar and bicarpelar. There are nectaries located in the center of the flower, two between the ovary and the short stamens and two between the long stamens and the petals (Fig 1).

The test of the exsudation from the nectaries indicated the carbohydrates presence in the nectar, reducing sugar and fructose. In field collections, during the period of 9:00 a.m. until 3 p.m., the occurrence of the polinator insects was observed, which were collecting nectar, and an increase in their populational density was registered from 11 a.m. until 15 p.m. In this period, larger yield was obtained.

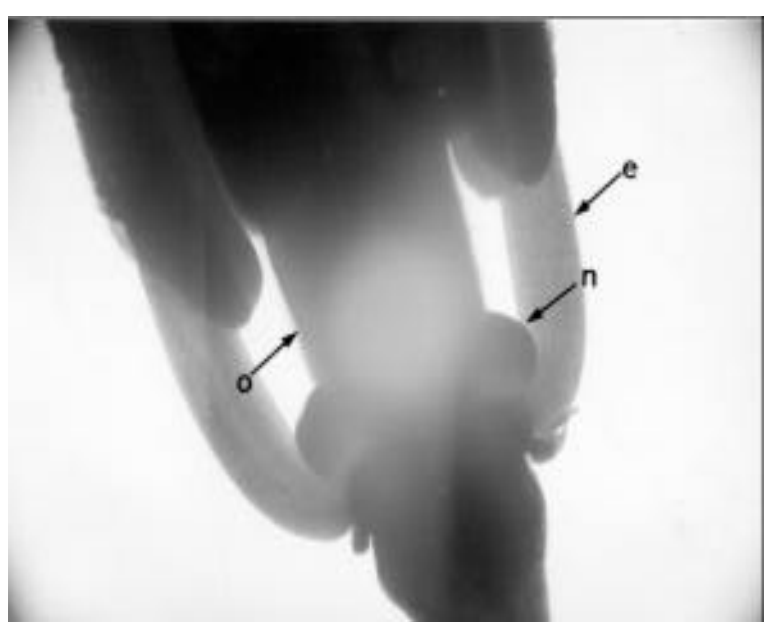

Figure 1. Nectaries (n) located between the short stamen (e) and the ovary (o); (increased of four fold). Dourados, MS, 1997.

\section{Floral biology in the pre-anthesis phase}


The floral buttons with 0.5 to $0.7 \mathrm{~cm}$ of length presented anthers below the stigma and papillas less developed (Fig 2).

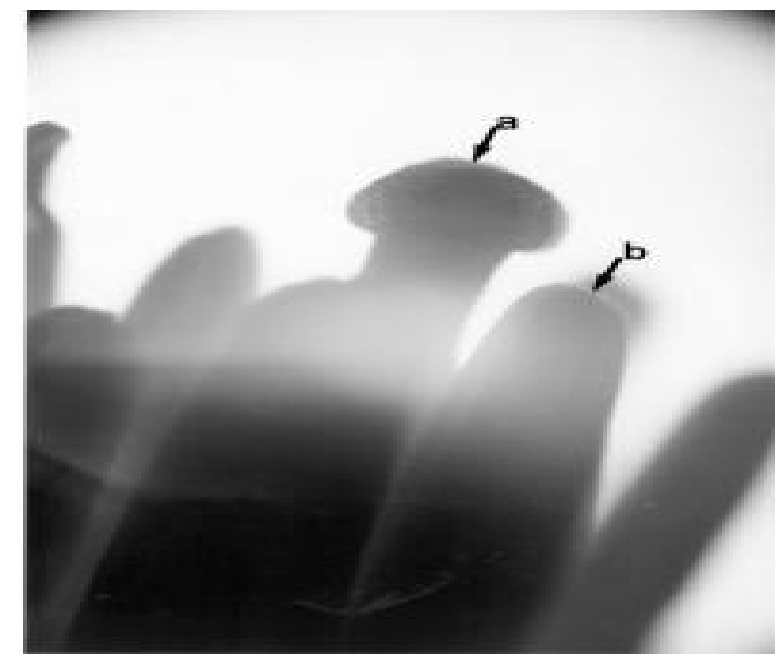

Figure 2. Large stamens below the stigma (a), anthers (b) begining the dehiscence. Dourados, MS, 1997.

The pollen placed on the stigma in the buttons with $0.6 \mathrm{~cm}$ of length formed fruits; the pollen grains were viable and with an abundant exina with lipid substances. In buttons with $0.8 \mathrm{~cm}$ of length, the corolla began to stand out, the petals exteriorize and the larger anthers begin the dehiscence from top to bottom, reaching the same height of the stigma (Fig 3).

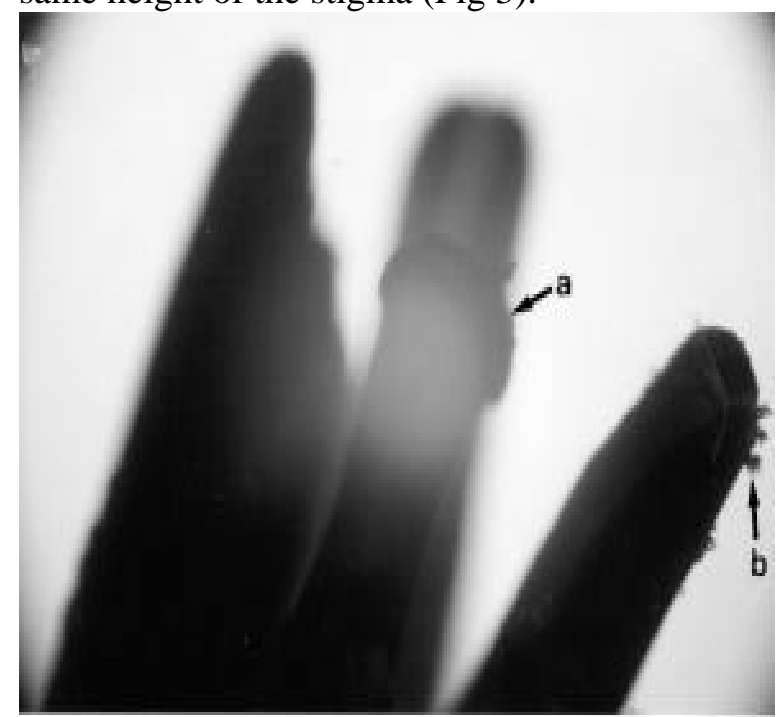

Figure 3. Anthers begin the dehiscence (b) from top to bottom, reaching the same height of the stigma (a). Dourados, MS, 1997.

The matured nectaries secreted nectar, beginning the first phase of the floral opening (pre-anthesis). When the flower became $1.0 \mathrm{~cm}$ of length, the larger anthers, totally open, surpassed the size of the stigma, depositing on this a mass of compatible and enough pollen to fecundate the ovules of a flower. This fact was confirmed through the sacking of the floral button and posterior transformation in fruit. The smaller anthers didn't reach the stigma in this phase. The pollen put down the stigma with high concentration of starch, which represented a primary source of energy for the polinators. The intra-floral nectaries produced nectar in great amount during the whole pre-anthesis phase. In this phase, it was observed that Trigona sp. landed in the floral buttons, tearing them and eating the anthers, searching pollen that was accumulated in the tibia. It held on the corolla with the aid of the legs and it began the cutting of the walls, using the jaws. This cutting was made in the place of nectar elimination and it enlarged progressively, resulting approximately in an circular opening, with a variable size. In agreement with the size of the hole, Trigona sp. introduced the buccal pieces there or even the head in it and it ingested the nectar. Afterwards, Trigona sp. retreated and lifted flight, abandoning the flower.

\section{Biology of the anthesis phase}

In the second phase, the flower reached the mean size with $1.3 \mathrm{~cm}$ of maximum length and $1.5 \mathrm{~cm}$ of diameter; the larger anthers began a torsion from within outside and the smallest ones could not reach the stigma, (due to the lengthening of the probe) (Fig 4).

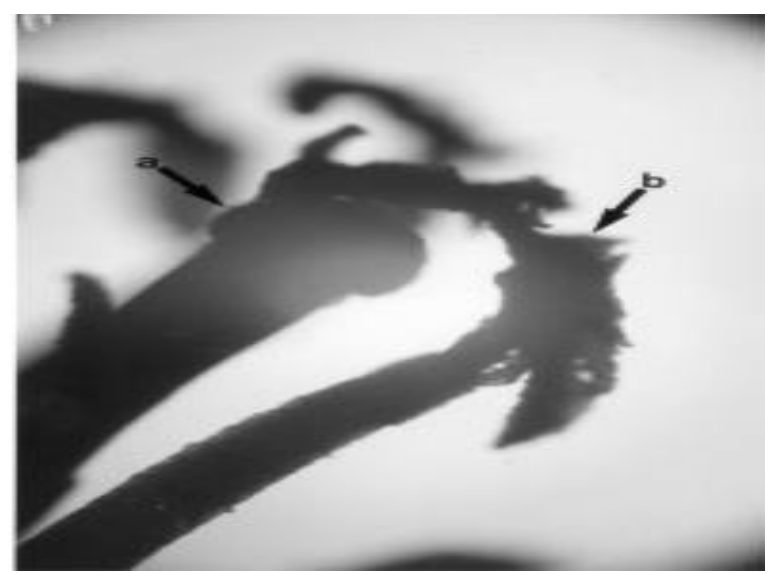

Figure 4. Larger stamens surpass the stigma (a); with the anthers (b) totally opened. Dourados, MS, 1997.

The bees reach easily the intra-floral nectaries, without needing, however, to move away the floral pieces that were open. When the insects visited the flowers in search of nectar, the pollen grains were stuck to their bodies, mainly in the ventral part and they were taken to the stigma of 
other flowers. In pre-anthesis, the buttons marked to evaluate the ragged time for the flower to reach the anthesis, it was observed that this was completed in about $20 \mathrm{~h}$, being the available rewards to the polinator for a mean period of $48 \mathrm{~h}$. In reason of the asynchronism and intermittence during the opening of their flowers, the floral activity during one day, stays intense, promoting a constant flow of reward to the insects visitors. The flowers of B. napus exhaled light scent, and it could be affirmed that this was one of the attractiveness to the polinators. According to Proctor \& Yeo (1975), the weak scent eliminated by some flowers, has a great importance to the bee's intra-floral behavior. Faegri \& Van Gives Pijl (1979), talking about the attraction of the insects by the scent, affirmed that this was usually, a secondary attractiveness, and it was very important for the recognition at any distance. Probably, the scent developed an important role when provoking instinctive reactions, especially in insects. The authors affirmed that the great amount of chemical energy spent in the production of the scent was evidenced by the disappearance of starch during the odoriferous phase of the anthesis. Similar results were observed during the anthesis phase when there was a decrease of the starch in flowers above $1.2 \mathrm{~cm}$ of length. There were larger amounts of starch in buttons below $1.0 \mathrm{~cm}$ this justifies the occurrence of insects pollen collectors, as $D$. speciosa (Coleoptera: Chrysomelidae), and Trigona sp. (Hymenoptera: Apidae), that tear the floral button in search of food.

\section{Biology of the post-anthesis phase}

In the third post-anthesis phase, the secretion of the nectaries was quite reduced, and the anthers, petals and sepals wither dropping soon after, with the remaining of the stigma that accompanies the fruit until the next ripening.

\section{Reproductive system}

Table 1 indicates the values obtained for the analysis of the characters in each test. It was observed that B. napus was an autogamous plant, which presented mechanisms for the occurrence of the alogamy, evidenced through the reproductive strategies that it used. According to Alberts et al. (1994), the reproductive strategies created new combinations in each generation, reducing the homozigose and the possibility of recessive characteristics, many of which were deleterious, as the vigor loss, that reduced the productivity. In agreement with Williams (1978) and Eisikowtich (1981), the flowers of B. napus were auto-fertile, presenting, however, the sterile smaller anthers. In the present work, the smaller anthers of cultivar CTC-4 presented viable pollen. However, in the pre-anthesis and anthesis stages, these anthers didn't reach the stigma, and did not participate in a noticeable form of the fertilization process. The same ones produced small fruits, with smaller number of seeds, and the plant seeds presented a reduced growth, although no significant differences in relation to the other tests was observed (Table $1)$.

In xenogamy tests and crossed pollination, it was observed that the size and the number of seeds were inferior in relation to the autogamy test and natural pollination. This happened probably, due to the manipulation accomplished in the floral button and in the stigma, during the emasculation and the pollen deposit. However, the seeds presented larger mean weight and also presented the plant seeds height, for the tests of crossed pollination and xenogamy. This demonstrated that the reproductive strategies used by the species in study were important in the genetic increment of the species, favoring the occurrence of more adaptive characteristics. In agreement with Dan et al. (1987) among the strategies, it was the largest growth rate, because they presented larger transformation capacity and supply of reservations of fabric storage and a larger incorporation of these for the embryonic axis. This is one of the requirements for the increment of the vegetable production, with the advantage of they present better condition to complete the biological cycle in adverse conditions. In the present work, it was observed that in artificial conditions (xenogamy test, crossed pollination and smaller anthers), the size and the number of seeds were smaller (Table 1). However, there is a possibility that in natural conditions, the alogamy happens with a larger 
frequency, due to mainly the high populational density of the polinators associated with the reproductive strategies of the plant. These differences are added in order to increase the development of important evolutionary characteristics for the species, as size of the fruit, number of seeds, and others. Independent to the reproductive system used by B. napus, the development of fruits happened in about $64 \%$ of the total inflorescence, miscarrying great part of the floral buttons and flowers of the apex. This was also observed by Almeida (1984) and Vidal et al. (1991) with different species of Crotalaria. Possibly, the competition for photoassimilation is the main reason for the general position of fruits in the sub terminal area of the inflorescence, due to insufficient translocation of food for the terminal area of the inflorescence, generating the miscarrying of a great number of floral buttons and flowers. Although pollen flow is intra (autogamia test) and inter-plant (presence of polinator insects and pollen grains stuck to its body), the same ones don't participate in a definitive way in the fertilization process, once the pollen liberated by the larger anthers is enough for the fertilization of the ovules. Through the accomplished studies, it was observed that, although neither the fruits obtained by the crossed pollination have been larger, nor presented larger number of seeds, the presence of the polinator was important to obtain fruits with seeds weighting larger. That indicates that there is a larger amount of nutritional reserve in the seed, favoring the germination and the development of the plant seeds.

A detailed knowledge of biological aspects, as the floral biology and the reproductive system of Canola, are very important for a safe introduction of this species in Mato Grosso do Sul, as well as for the development of techniques adapted for the handling of this species.

Table 1. Values of the mean size of the fruits/plant (T.F), mean number of the seeds/plant (N.S), mean weight of 10 seeds (P.S), average of the germination of 10 seeds (G.E.R.M) and mean size of 10 plant seeds (T.P) of B. napus, in function of different reproductive systems, natural pollination, floral button sacking, Inflorescence sacking, crossed pollination, xenogamy, smaller anthers. Dourados,MS, 1997.

\begin{tabular}{lccccc}
\hline & \multicolumn{5}{c}{ APPRAISED CHARACTERS $*$} \\
\hline Reproductive system & T.F $(\mathrm{cm})$ & N.S & P.S $(\mathrm{mg})$ & GERM. $(\%)$ & C.P $(\mathrm{cm})$ \\
\hline Natural pollination & $5.0 \mathrm{a}$ & $22.9 \mathrm{a}$ & $28.8 \mathrm{~b}$ & $93.9 \mathrm{a}$ & $8.6 \mathrm{ab}$ \\
Floral button sacking & $4.3 \mathrm{ab}$ & $15.6 \mathrm{ab}$ & $36.0 \mathrm{ab}$ & $84.3 \mathrm{a}$ & $8.1 \mathrm{ab}$ \\
Inflorescence sacking & $5.4 \mathrm{a}$ & $21.3 \mathrm{a}$ & $28.8 \mathrm{~b}$ & $90.4 \mathrm{a}$ & $8.2 \mathrm{ab}$ \\
Crossed pollination & $3.0 \mathrm{bc}$ & $5.07 \mathrm{c}$ & $40.2 \mathrm{a}$ & $95.2 \mathrm{a}$ & $9.1 \mathrm{ab}$ \\
Xenogamy & $3.5 \mathrm{~b}$ & $11.1 \mathrm{~b}$ & $39.8 \mathrm{a}$ & $95.2 \mathrm{a}$ & $9.6 \mathrm{a}$ \\
Smaller anthers & $2.0 \mathrm{c}$ & $2.9 \mathrm{c}$ & $35.8 \mathrm{ab}$ & $80.0 \mathrm{a}$ & $4.3 \mathrm{~b}$ \\
C.V $(\%)$ & 22.22 & 25.73 & 10.59 & 14.49 & 23.17
\end{tabular}

*Averages followed by a same letter in the columns don't differ estatistically, at the level of 5\% of probability by the test of Tukey.

\section{RESUMO}

Os estudos da biologia floral da Canola (cultivar CTC-4), objetivando o conhecimento do sistema reprodutivo e de suas estratégias reprodutivas foram realizados em Dourados-MS. B. napus é autopolinizada, apresentando no entanto, muitos recursos para realização de alogamia, como por exemplo pólen abundante, néctar e odor. As anteras menores foram responsáveis pela produção de frutos com sementes de vigor inferior, quando comparadas aos testes de autogamia, polinização natural e cruzada.

\section{BIBLIOGRAPHY}

Alberts, B.; Bray, D.; Roberts, M. R. K.\& Watson, J. D. (1994), Molecular Biology 
of the cell. New York/London, Garland Publishing.

Almeida, E. C. de. (1984), Contribuição ao estudo do ciclo biológico e sistema de reprodução de Crotalaria mucronata Desv. (Papilionoideae). Tese Mestrado Rio de Janeiro. UFRJ. Brasil.

Barroso, G. M. (1978), Sistemática de angiospermas do Brasil. Universidade de São Paulo, LTC/EDUSP, v.1, 234 p.

Dafni, A. (1992), Pollination Ecology - A pratical approach. Oxford: Oxford University. Press. 544p.

Dan, E. L.; Mello, V. D. C.; Wetzel, C. T.; Popinigis, F. \& Souza, E. P. (1987), Transferência de matéria seca como método de avaliação do vigor de semente de soja. Revista Brasileira de Sementes, 9(3): 45-55.

Dias, J. C. A. (1992), Canola/colza-alternativa de inverno com perspectivas de produção de óleo comestível e energético. Capão do Leão: EMBRAPA-CPATB. Boletim de Pesquisa, 3, Pelotas,. 46p.

Eisikowitch, D. (1981), Some aspects of pollination of oil-seed rape (Brassica napus L.). Journal of Agricultural Science, 96,321-326.

Faegri, K.; Van Der Pijl, L. (1979), The principles of pollination ecology. $\quad 3^{\mathrm{a}} \mathrm{ed}$., Oxford: Pergamon,. 291p.

Free, J. B.,Nuttall, P. H. (1968), The pollination of oil seed rape (Brassica napus L.) and the behaviour of bees on the crop. Journal of Agricultural Science, 71,91-94.

Johansen, D. A. (1940), Plant microtechnique. New york: McGraw-Hill,. 523p.
Lawrence, G. H. (1966), Taxonomy of vascular plants. New York: Macmillan, 823p.

Linsley, E. C.\& Cazier, M. A. (1963), Further observation on bee which take pollen from plants of the genus Solanum. Fan. Pacif. Ent., 39, 1-18.

Martin, N. B.\& Junior, S. N. (1993), Canola: uma alternativa agrícola de inverno para o centro-sul brasileiro. Informações Econômicas., 23,9-23.

Morita ,T.\& Assumpção, R. M. U. (1972) Manual de soluções, reagentes e solventes. São Paulo: Ed. Edgar Blucher,. 672p.

Proctor, M.\& Yeo, P. (1975), The pollination of flowers. William Collins Sons e Co. Ltda., $2^{\mathrm{a}}$. ed. London.. 418p.

Vidal, M. R. R.; Vidal, W.N.; Almeida, E. C.; Mussury, R. M. A. (1991), Sistema reprodutivo de Crotalaria zanzibarica Benth. (Leguminosae - Papilionoideae). Revista Ceres, 38, 431-437.

Williams, I. H. (1985), The polinnization of swede rape (Brassica napus L.). Bee World., 66, 16-20.

Williams, I. H. (1980), Oil-seed rape and beekeeping, particularly in Britain. Bee World., 61, 141-153.

Williams, I. H. (1978), The pollination requirements of swede rape (Brassica napus L.) and of turnip rape (Brassica campestris L.). Journal of Agricultural Science, 91, 343-348. 